\title{
SEJARAH CIJULANG (Kajian Struktural, Semiotik, dan Etnopedagogik)
}

\author{
Dini Novianti Sutrisna \\ Pos-el: nsdini_834@yahoo.co.id
}

\begin{abstract}
ABSTRAK
Penelitian ini berjudul "Sajarah Cijulang (Ulikan Struktural, Semiotik, jeung Étnopédagogik)". Penelitian ini membahas naskah Sajarah Cijulang dari segi struktural, semiotik, dan etnopedagogiknya. Latar belakang penelitian ini adalah karena masih sedikitnya penelitian tentang naskah Sajarah Cijulang, selain itu naskah Sajarah Cijulang masih digunakan atau bibacakan secara rutin oleh masyarakat Cigugur, kabupaten Pangandaran pada bulan Muharam, bulan Maulud, dan pada malam-malam kliwon tertentu, tapi masih banyak masyarakat yang tidak mengetahui keadaan dan isi naskah ini. Penelitian ini bertujuan untuk memahami isi salah satu karya sastra, bisa mengungkap nilai-nilai budaya lama sebagai langkah dalam memelihara budaya nasional, serta untuk mengenal hasil pemikiran masyarakat jaman dulu. Metode penelitian yang digunakan adalah metode deskriptif analisis. Teknik pengumpulan data yang digunakan dalam penelitian ini adalah teknik dokumentasi dan studi pustaka. Dari hasil penelitian terlihat bahwa alur cerita Sajarah Cijulang menggunakan alur maju yang dibagi menjadi beberapa episode. Karakter dalam naskah Sajarah Cijulang merupakan tokoh-tokoh fiksi dan tokoh-tokoh sejarah. Latar yang ada dalam cerita Sajarah Cijulang merupakan tempat-tempat yang ada disekitar daerah Cijulang. Dalam naskah Sajarah Cijulang ditemukan 59 unsur semiotik yang meliputi ikon 8,5\%, indeks 59,3\%, simbol 32,2\%. Dari hasil analisis naskah Sajarah Cijulang ditemukan 146 nilai etnopedagogik yang meliputi nilai etnopedagogik moral kemanusiaan 45,2\%, gapura panca waluya 32,9\%, dan catur jatidiri insan $21,9 \%$.
\end{abstract}

Kata Kunci: Sajarah Cijulang, struktural, semiotik, etnopedagogik

\section{SAJARAH CIJULANG \\ (The Study of Structure, Semiotics, and Ethnopedagogy)}

\begin{abstract}
This study is entitled Sajarah Cijulang (The Study of Structural, Semiotics, and Ethnopedagogy. This study discusses the manuscript of Sajarah Cijulang in terms of structural, semiotic, and ethnopedagogy. The background of this research is because there are still a small number of researches on the manuscript of Sajarah Cijulang. In addition, the manuscript of Sajarah Cijulang is still read regularly by the people of Cigugur, Pangandaran Regency in the month of Muharram, Maulud, and on several kliwon nights. However, many people still do not know the facts and the content of the manuscript. This study aims to understand the contents of the literary work, to uncover old cultural values as a step in preserving the national culture, as well as to know the ideas of the ancient society. This study used descriptive analysis method. The data collection techniques employed in this study was documentation and technical literature. The study revealed that the storyline of Sajarah Cijulang has forward plot that can be divided into several episodes. The characters in Sajarah Cijulang are fictional characters and historical characters. The backgrounds in Sajarah Cijulang are places that exist around the Cijulang area. In the manuscript of Sajarah Cijulang, 59 semiotic elements were found. They include $8.5 \%$ of icons, 59.3\% of indexes, $32.2 \%$ of symbols. From the analysis, 146 etnopedagogical values were found in Sajarah Cijulang. The values are $45.2 \%$ of human moral, $32.9 \%$ of gapura panca waluya, and $21.9 \%$ of catur jatidiri insan.
\end{abstract}

Keywords: Sajarah Cijulang, Structural, Semiotics, Ethnopedagogy 


\section{PENDAHULUAN}

Naskah Sejarah Cijulang merupakan salahsatu naskah yang masih dikeramatkan oleh sebagian kelompok masyarakat. Mereka percaya terhadap beberapa mitos yang berkaitan erat dengan sejarah Cijulang. Seperti naskah itu tidak boleh dibaca pada hari Selasa dan hari Sabtu, tidak boleh di foto, dan tidak boleh dipinjamkan kepada sembarang orang.

Naskah Sejarah Cijulang masih dibaca oleh masyarakat kecamatan Cigugur, kabupatén Pangandaran pada bulan MUharam, bulan Maulud, dan malam-malam kliwon tertentu. Walaupun demikian, tidak semua masyarakatnya mengetahui naskah Sejarah Cijulang.

Untuk mengetahui bagaimana gambaran Sejarah Cijulang dan mengungkap isinya, tentu harus menggunakan teori tertentu. Teori yang digunakan yaitu strukturalisme, semiotik, dan etnopedagogik. Menurut Hawkes dalam Pradopo (2010, hal. 37) strukturalisme dipandang selaku cara berfikir mengenai dunia sastra yang merujuk pada susunan hubungannya. Dengan demikian, setiap unsur dalam sistem struktur akan mempunyai makna apabila berhubungan dengan unsur yang lain.

Dalam ilmu sastra, "strukturalisme" merupakan kelompok-kelompok gejala yang erat kaitannya. Misalnya: pelakupelaku dari sebuah novel bisa dibagi menjadi: tokoh utama, antagonis, tokoh pelengkap, dsb. Pembagian seperti itu didasari oleh hubungan yang erat antar pelaku. Antara pelaku utama dan pelaku tambahan ada hubungan asosiasi, antara pelaku utama dan pelaku protagonist ada hubungan oposisi. Hubungan tersebut bersifat tetap, tidak berubah (Luxemburg, dkk., 1992, hal. 36).

Menurut Stanton (2007, hal. 20) teori fiksi dibagi menjadi tiga, yaitu fakta cerita, tema, dan sarana sastra. Fakta dalam sebuah cerita mencakup alur, karakter, dan latar. Ketiga unsur fiksi tersebut berfungsi sebagai catatan kejadian imajinatif dari sebuah cerita. Apabila dirangkum menjadi satu, ketiga unsur itu disebut struktur factual atau tingkatan factual cerita.

Alur merupakan rangkaian kejadiankejadian dalam sebuah cerita. Istilah alur biasanya terbatas pada kejadian-kejadian yang mempunyai hubungan kausalitas saja, suatu kejadian menyebabkan atau disebabkan oleh kejadian lain Stanton (2007, hal. 33), istilah karakter bisa diterapkan pada dua konteks. Konteks pertama, karakter merujuk pada tokoh-tokoh yang muncul dalam cerita. Konteks kedua, karakter merujuk pada campuran dari berbagai kepentingan, keinginan, emosi, dan prinsip moral dari tokoh-tokoh yang ada dalam cerita. Karakter seorang tokoh bisa terlihat dari nama tokoh itu sendiri, bisa juga terlihat dari deskripsi dan komentar pengarang pada seorang tokoh.

Stanton (2007, hal. 35) menyebutkan latar merupakan lingkungan yang mencakup suatu kejadian dalam cerita, semesta yang mempunyai interaksi dengan kejadiankejadian yang sedang berlangsung. Latar bisa berwujud tempat, bisa juga berwujud waktu-waktu tertentu (hari, bulan, dan tahun), cuaca, atau suatu periode sejarah.

Kata semiotik berasal dari bahasa Yunani yaitu semeion, yang berarti tanda. Semeion merupakan cabang ilmu yang mempelajari tanda dan segala hal yang berhubungan dengan tanda (Syuropati, 2003, hal. 66).

Dilihat dari objeknya, Peirce membagi tanda menjadi tiga, yaitu ikon (icon), indeks (index), dan simbol (symbol) (Budiman, 2011, hal. 78).

Ikon merupakan tanda yang berdasar pada persamaan atau kemiripan (resemblance) antara representamen dengan objeknya. Ikon tidak hanya mencakup citracitra realistis seperti pada lukisan atau foto saja, tapi mencakup ekspresi-ekspresi berupa grafik, skema, peta geografis, persamaan matematis, dan metafora.

Indeks merupakan tanda yang mempunyai hubungan fenomenal atau eksistensial antara representamen dan objeknya. Dalam indeks antara tanda dan objeknya 
mempunyai hubungan yang konkret, aktual, serta biasanya melalui suatu cara yang sekuensial atau kausal. Indeks bisa berupa zat atau barang material, gejala alam, gejala fisik, suara, dan goresan.

Simbol merupakan tanda yang representamennya merujuk pada objek tertentu tanpa adanya motivasi (unmotivated). Simbol terbentuk melalui konvensi-konvensi atau kaidah-kaidah tanpa adanya hubungan langsung antara representamen dengan objeknya, atau mempunyai sifat arbitrer.

Berkaitan dengan etnopedagogik, Ruhaliah (2015, hal. 45) menyebutkan etnopedagogik adalah ilmu yang berdasar kepada budaya dan adat kebiasaan masyarakat yang harus dilestarikan, supaya maju dan berkembang, dan terwujud menjadi kehidupan yang unggul.

Orientasi etnopedagogik Sunda menciptakan Catur Jatidiri Insan sebagai manusia unggul (Maung), yakni pengkuh agamana (spiritual quotient), luhung élmuna (intelektual quotient), jembar budayana (emotional quotient), jeung rancagé gawéna (actional quotient) (Suryalaga dalam Sudaryat, 2014, kc. 124).

Etnopedagogik Sunda mendorong kegiatan pendidikan dan pembelajaran untuk memasuki Gapura Panca Waluya, yakni cageur, bageur, bener, pinter, singer, yang dikukuhkan dengan karakter pangger (Sudaryat, 2014, kc. 127).

\section{METODE}

Metode yang digunakan dalam penelitian ini yaitu metode deskriptif analisis. Metode deskriptif analisis dalam penelitian ini digunakan untuk mendeskripsikan struktur cerita, unsur semiotik, dan nilai etnopedagogik yang ada dalam naskah Sejarah Cijulang. Sumber data yang digunakan dalam penelitian ini yaitu naskah Sejarah Cijulang koleksi Perpustakaan Nasional Republik Indonesia (PNRI) nomer katalog SD 206B. Teknik yang digunakan dalam penelitian ini adalah teknik dokumentasi dan studi pustaka.

\section{HASIL DAN PEMBAHASAN}

Fakta cerita menurut Stanton mencakup: alur, karakter, dan latar. Alur cerita Sejarah Cijulang menggunakan alur maju yang dibagi kedalam beberapa episode. Cerita setiap episodenya ada yang lengkap, ada juga yang hanya menyebutkan tokoh dan keturunannya. Oleh karena itu yang dianalisis hanya tiga episode uatama yang ceritanya dianggap lengkap.

1. Episode pertama menceritahan asal mula diciptakannya alam dunia, Nabi Adam, dan silsilah raja-raja Sunda (GaluhPajajaran). Hal itu seperti terlihat pada catatan dibawah ini.

\section{Bismillahirraohmanirrohiim \\ Ikilah sajarah purwaning jagat kang gumelar sakabéh.}

Tetkala awang-awang uwung-uwung durung ana kang sawiji-wiji, la ta'yun gaibu'lguyub arané. Mangka aya kersa méméh aya anu dikersakeun, dingaranan naktu gaib. Mangka aya kersa anu dikersakeun, dingaranan a'yan thabitah. Mangka aya warna rupa, dingaranan 'alam arwah roh idopi.

Mangka Alloh ta'ala ngersakeun ngadamel adam tapel; lajeng Alloh ta'ala angandika maring malaikat Jibril: Ya Jibril, manéh kudu leumpang bumi tujuh langit

tujuh, cokot lemah putih saking kasucian ningsun

Mangka nuli angalih Raja Putri ka Gunung Padang, nuli sujud di Gunung Padang. Tatkala eukeur sujud, mangka nuli metu cahya tina socané, mangka iku dingaranan Ratu Galuh.

Mangka lawas-lawas ia ratu Galuh, nuli dadi nyakrawati ing Nusa Jawa.

2. Episode kedua menceritakan cerita perjalanan Aki Gede dan Nini Gede orang Kedungrandu yang melakukan 
perjalanan dari Kedungrandu sampai ke Gurago. Hal itu seperti terlihat pada catatan dibawah ini.

Ieu nyarioskeun babad karuhun anu asal Kedungrandu, wasta Nini Gedé Aki Gedé. Éta sadérékna 4, pameget sadaya. 1 Sembah Jang Pati, anu di Ciamis; 2 Sembah Jang Raga, anu di Karangsimpang; 3 Sembah Jang Singa, anu di Panjalu; 4 Sembah Jang Langas, anu di Cijulang.

3. Episode ketiga menceritakan Sembah Agung yang berada di Taal. Hal tersebut seperti terlihat pada catatan di bawah ini.

Ieu pasal nyarioskeun Sembah Agung anu di Ta'al.

Saangkatna ti Cihaur, lajeng lalampah $k a$ sagara, meunang tilu taun. Ari parantos tilu taun, lajeng deui angkat ngalalakon, lawas-lawas sumping ka Sukapura, ka Dalem Tambéla.

Karakter dalam naskah Sejarah Cijulang merupakan tokoh-tokoh fiksi dan tokoh-tokoh sejarah. Tokoh-tokoh yang terbilang jadi pusat dalam cerita Sejarah Cijulang ini diantaranya Aki Gede, Nini Gede, anak perempuan Aki Gede, Sembah Ragasangsang, kerabat Aki Gede yang di Banyumas, Kangjeng Sinuhun, Dalem Tambela, Sembah Agung, Nyi Putri (anak Dalem Tambela), Raden Haji, Ratu Galuh, anak cucu Ratu Sunda, Ratu Sunda, Suktan Suldi, Sultan MUradi, Prabu Wasek, dan Sembah Jang Langas.

\section{1) Aki Gede atawa Sembah Gede}

Aki Gedé miboga sikep kukuh kana pamadeganana, sabar, wijaksana, sarta boga jiwa kapamingpinan. Hal éta katitén dina cutatan ieu di handap.

Aki Gede memiliki sifat teguh pendirian, sabar, bijaksana, serta mempunyai jiwa kepemimpinan. Hal itu terlihat dari catatan di bawah ini.
Ti dinya putrana dipundut $k u$ Kangjeng Sinuhun, ari ku Nini jeung ku Aki teu disanggakeun; nepi ka tujuh kali mundut, henteu disanggakeun baé.

Ari geus kitu disaur, Nini Gedé Aki Gedé, sarta tuluy nemonan.

Teu lila jol deui serat ti dalem Tambela, nepi ka tujuh kali.

Ari panutupna, pok deui Aki Gedé ngalahir ka mantuna: "Kedungrandu ogé, lantaran ngabélaan anak. Ayeuna geus di dieu, dipundut deui ku nu kagungan nagara. Ayeuna mah sugan urang sanggakeun baé, mana kitu ogé geus takdir diri urang."

Ari walon mantuna: "Nya mangga baé atuh."

\section{2) Nini Gede}

Nini Gede memiliki watak yang sama dengan Aki Gede, teguh pendirian. Watak yang lainnya tidak diceritakan. Hal itu terlihat seperti di bawah ini.

Ti dinya putrana dipundut $k u$ Kangjeng Sinuhun, ari ku Nini jeung ku Aki teu disanggakeun; nepi ka tujuh kali mundut, henteu disanggakeun baé.

Ari geus kitu disaur, Nini Gedé Aki Gedé, sarta tuluy nemonan.

\section{3) Anak Perempuan Aki Gede}

Anak perempuan Aki Gede memiliki watak sabar, patuh kepada kedua orang tua dan suaminya. Hal itu terlihat ketika dirinya diserahkan kepada Dalem Tambela, dia hanya menuruti keputusan ayah dan suaminya. Hal tersebut terlihat dalam catatan di bawah ini.

Énggalna lajeng bae disanggakeun ku carogena ka Dalem Tambela.

Ari carogéna barang sumping $k a$ Gurago, sup ka mitoha teu betah, sup ka sadérék-sadérékna teu betah. 
4) Sembah Ragasangsang (menantu Aki Gede)

Sembah Ragasangsang memiliki watak pasrah, baik, serta bijaksana. Hal itu terlihat pada catatan di bawah ini.

Teu lila jol deui serat ti dalem Tambela, nepi ka tujuh kali.

Ari panutupna, pok deui Aki Gedé ngalahir ka mantuna: "Kedungrandu ogé, lantaran ngabélaan anak. Ayeuna geus di dieu, dipundut deui ku nu kagungan nagara. Ayeuna mah sugan urang sanggakeun baé, mana kitu ogé geus takdir diri urang."

Ari walon mantuna: "Nya mangga baé atuh."

5) Kerabat Aki Gede yang di Banyumas

Kerabat Aki Gede yang di Banyumas memiliki sifat baik kepada keluarganya. Hal itu terlihat pada catatan dibawah ini.

Ari eukeur ngadawuh kitu, aya sadérékna anu ti Banyumas: atuh buruburu baé ka Kedungrandu bari nyarita, pokna: "Nini, Aki kaula ngadéngé dawuhan Kangjeng Sinuhun yén Nini jeung Aki rék dirurugan. Ayeuna ulah tiis-tiis jahé, kudu geuwat baé leumpang ka Kulon!",

6) Kangjeng Sinuhun

Kangjeng Sinuhun memiliki sifat dictator, semaunya sendiri. Hal itu terlihat pada catatan di bawah ini.

Ari geus marulih, lajeng baé digunemcaturkeun ku Kangjeng Sinuhun Dawuhanana: "Kumaha ta Nini Gedé, Aki Gedé dipundutan mu'jijat kieu-keiu, ngajadi baé, henteu aya anu pogog. Kawasna ngan kudu dirurugan baé ayeuna mah ku kami."
7) Dalem Tambela (Dalem Sukapura)

Dalem Tambela memiliki sikap yang bijaksana serta menghargai orang lain, tidak memaksakan kehendaknya sendiri. Hal itu terlihat pada catatan di bawah ini.

Lila-lila pok Dalem Tambela ngadawuhan kieu: "Éh, Agus, éta pamajikan Agus, keur kami baé, nya!"

Ari piunjukna mantu Aki Gedé: "Sumuhun narah gusti."

Ari geus beurang, tuluy mantu Aki téh marulih.

Teu sakumaha lilana ti barang marulih tas ngadeuheusan téa, jol aya serat ti Dalem Tambéla, unggelna mundut putra Aki, pamajikan utusan téa. Tapi teu diwaro.

Teu lila jol deui serat ti dalem Tambela, nepi ka tujuh kali.

8) Sembah Agung

Sembah Agung memiliki sifat senang memperlihatkan kemampuan dan keahliannya, serta memiliki sikap tanggung jawab. Hal itu terlihat pada catatan di bawah ini.

Harita Dalem Tambela ngadawuhan, dawuhanana: "Sahasaha anu bisa nganggeuskeun Situ Cimawaté, top baé anak kaula."

Sembah Agung barang ngadangu, pok anjeunna unjukan yeu rék nyobanyoba.

Sanggeus kawidian ku Dalem Tambela, lajeng ku Sembah Agung dipidamel. Ngan kénging sapoé sapeuting parantos situ téh.

$\mathrm{Ti}$ dinya lajeng unjukan $\mathrm{ka}$ Kangjeng Dalem bari nyuhunkeun diuninga.

Lajeng $k u \quad K a n g j e n g$ Dalem ditingali.

Ari dawuhan Kangjeng Dalem: "Ambu-ambu atuh ieu mah peryoga pisan, sarta rempug jeung karep kami." 
9) Nyi Putri (anak Dalem Tambéla)

Nyi Puti memiliki sifat penurut, serta penyayang. Hal itu terlihat pada catatan di bawah ini.

Ti dinya lajeng putri dicandak $k u$ Sembah Agung, lajeng angkat ka Wétan.

10) Radén Haji

Raden haji memiliki sifat kurang tanggung jawab terhadap pekerjaan, sabar, memiliki usaha untuk mempertahankan apa yang dimilikinya. Hal itu terlihat pada catatan di bawah ini.

Ari Dalem Tambéla, harita keur miwarang nyitu Cimawaté, ari anu dipiwarang, piminantueunana, wastana Radén Haji; nanging henteu tiasa parantos.

\section{1) Ratu Galuh}

Ratu Galuh memiliki watak sombong, takabur, sebab merasa memiliki kesaktian dan kekuasaan. Hal itu terlihat pada catatan di bawah ini.

Mangka nuli angalih Raja Putri ka Gunung Padang, nuli sujud di Gunung Padang. Tatkala eukeur sujud, mangka nuli metu cahya tina socané, mangka iku dingaranan Ratu Galuh.

Mangka lawas-lawas ia ratu Galuh, nuli dadi nyakrawati ing Nusa Jawa.

12) Anak cucu Ratu Sunda

Anak cucu Ratu Sunda memiliki sifat teguh pendirian, baik, sabar, walaupun di usir oleh ayahnya. Hal tersebut terlihat pada catatan di bawah ini.

Punika margané anak putu Ratu Sunda bubaran saking Pajajaran, ditundung ku kang rama sanggeus meunang wurukan ti Kiyai An Sancang samulihna saking Mekah, nuli ka putra kekel imanna lan islamna, tegesna henteu anut kana syaré'at kang rama; margané ditundung, sabab matak pamos ka nagara Pakuan, anu matak leumpang ka ratu Cempa.

\section{3) Ratu Sunda}

Ratu Sunda memiliki sifat tegas, apabila ada yang melawan perintahnya, walaupun anaknya sendiri akan di usir dari negaranya. Hal itu terlihat pada catatan di bawah ini.

Punika margané anak putu Ratu Sunda bubaran saking Pajajaran, ditundung $k u$ kang rama sanggeus meunang wurukan ti Kiyai An Sancang samulihna saking Mekah, nuli ka putra kekel imanna lan islamna, tegesna henteu anut kana syaré'at kang rama; margané ditundung , sabab matak pamos ka nagara Pakuan, anu matak leumpang ka ratu Cempa.

\section{4) Sultan Muradi}

Sultan Muradi memiliki sifat adil, tegas, dan menegakan kebenaran. Hal tersebut terlihat pada catatan di bawah ini.

Lan lamun sampun teka jangjiné kang rama, mangka matuk maring Mekah, maring kang raka. Lan sapun parapta maring gagaman, kaya wong arep angrurug, lamun ana ratu baha maring kersané Tuhan, kang sinungan nyakrawati di nusa Jawa.

Latar yang dianalisis dari naskah Sejarah Cijulang ini terpusat pada episode perjalanan Aki Gede dan Nini Gede dari Kedungrandu ke Gurago. Dalam naskah Sejarah Cijulang latar tempatnya merupakan tempat-tempat yang ada disekitar daerah Cijulang. Adapun latar waktu dan keadaan tidak disebutkan secara gambling. Latar tempat yang ada dalam naskah Sejarah Cijulang diantaranya bisa terlihat dalam catatan di bawah ini.

$T i$ dinya lajeng netepkeun putrana hiji anu ngeusian éta lembur, anu jenengan Sang Perbu Lajeng Jagat. 
Ari Nini, Aki, jeung saréncangna, tuluy angkat deui ngulon, lajeng ngidul. Barang sumping ka pasir, lajeng lirén, ngaso. Ayeuna éta tempat katelah Cikaso.

Ti dinya lajeng angkat deui. Ari geus jauh hég lirén deui, prak ngadamel imah hiji, balé hiji. Ayeunana éta lembur katelah Kalémba.
Analisis unsur semiotik dalam penelitian ini menggunakan teori Peirce yaitu menginterpretasikan tanda-tanda yang termasuk ke dalam ikon, indeks, dan simbol.

Ikon yang ditemukan dalam naskah Sejarah Cijulang ada lima, meliputi ikon imaji dan ikon metafora.

Tabel 1: Analisis Unsur Ikon

\begin{tabular}{|c|c|c|c|c|c|c|}
\hline \multirow{2}{*}{ No. } & \multirow{2}{*}{ Kode Data } & \multirow{2}{*}{ Referent } & \multicolumn{3}{|c|}{ Tipe } & \multirow{2}{*}{ Interprétasi } \\
\hline & & & Img. & Dgm. & Mfr. & \\
\hline 1. & $\mathrm{SC} / 21 / 7 / 3$ & $\begin{array}{l}\text { Bubulak } \\
\text { Karangsimpang }\end{array}$ & $\sqrt{ }$ & & & $\begin{array}{l}\text { Bubulak Karangsimpang } \\
\text { merupakan tanda yang } \\
\text { menunjukan "bubulak" } \\
\text { tempat Aki Gede dan } \\
\text { pengikutnya membuat } \\
\text { pasakan untuk dimakan ketika } \\
\text { dalam perjalanan dari } \\
\text { Kedungrandu. Hal itu terlihat } \\
\text { pada catatan di bawah ini. } \\
\text { Barang sumping ka bubulak, } \\
\text { tuluy olah-olah, bararang } \\
\text { tuang. Mangka ayeunana } \\
\text { katelah Bubulak } \\
\text { Karangsimpang. }\end{array}$ \\
\hline 2. & $\mathrm{SC} / 21 / 8 / 3$ & Binangun & & & $\sqrt{ }$ & $\begin{array}{l}\text { Kata Binangun merupakan } \\
\text { tanda dari dibangunnya } \\
\text { beberapa bangunan di suatu } \\
\text { tempat yang jadi perhentian } \\
\text { Aki Gede dalam } \\
\text { perjalanannya. Hal itu terlihat } \\
\text { pada catatan di bawah ini. } \\
\text { Barang sumping ka hiji } \\
\text { tempat, lajeng lirén. Di dinya } \\
\text { prak ngadamel pondok hiji, } \\
\text { sumur hiji. Anu ayeuna } \\
\text { katelah lembur Binangun. }\end{array}$ \\
\hline 3. & $\mathrm{SC} / 28 / 8 / 4$ & Kalénwadas & $\sqrt{ }$ & & & $\begin{array}{l}\text { Kalénwadas merupakan tanda } \\
\text { dari ditemukannya kain bekas } \\
\text { wawadas. Hal itu terlihat pada } \\
\text { catatan di bawah ini. } \\
\text { Ti dinya teras } \\
\text { angkat ngétan, kapendak } \\
\text { lamak urutna, wawadas. Mana } \\
\text { aya lembur ngaran } \\
\text { Kalénwadas. }\end{array}$ \\
\hline
\end{tabular}

Indeks yang ditemukan dari naskah Sejarah Cijulang sebanyak 35, yang meliputi indeks zat atau material, aktualisasi, tingkah-laku, gejala alam, dan gejala fisik. Beberapa indeks yang ditemukan seperti terlihat pada table di bawah ini. 
Tabel 2: Analisis Unsur Indéks

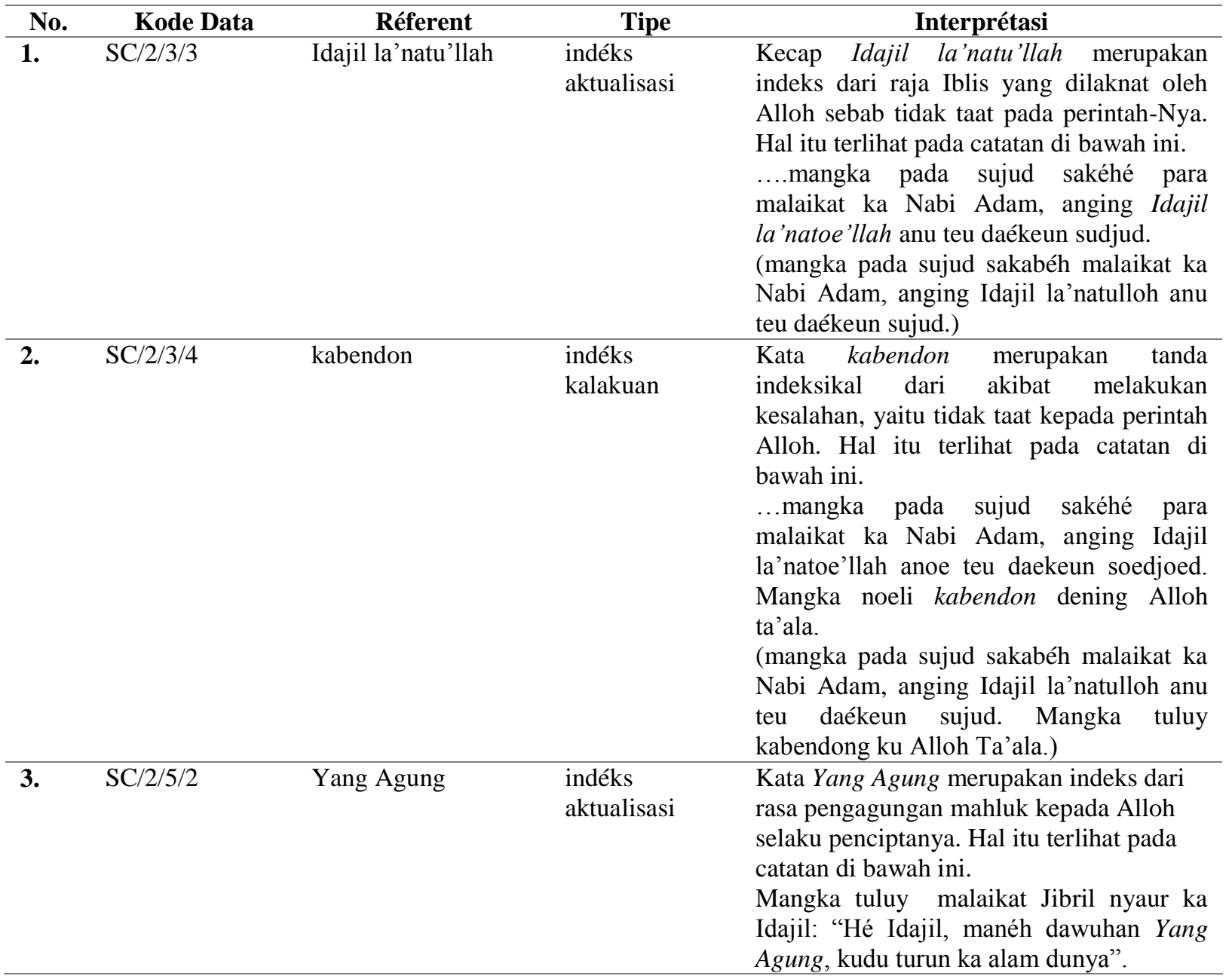

Simbol yang ditemukan dalam naskah Sejarah Cijulang ada 19. Dalam naskah Sejarah Cijulang banyak kata-kata yang mengandung simbol, tapi tidak semua kata itu dianalisis, hanya kata-kata yang menimbulkan multitapsir. Beberapa analisis seperti terlihat pada tabel di bawah ini.

Tabel 3: Analisis Unsur Simbol

\begin{tabular}{|c|c|c|c|}
\hline No. & Kode Data & Réferent & Interprétasi \\
\hline 1. & $\mathrm{SC} / 4 / 7 / 2$ & pakaél-kaél cinggir & $\begin{array}{l}\text { Pakaél-kaél cinggir merupakan simbol dari } \\
\text { hubungan atau posisi yang dekat antara Nabi } \\
\text { Adam dan Babu Hawa. Hali itu terlihat pada } \\
\text { catatan di bawah ini. } \\
\text { Tuluy baé angkat tina panglinggihanana } \\
\text { reujeung Babu Hawa, bari pakaél-kaél cinggir. }\end{array}$ \\
\hline 2. & $\mathrm{SC} / 8 / 5 / 8$ & Nyai Sri & $\begin{array}{l}\text { Nyai Sri merupakan simbol padi yang ada di } \\
\text { Pulau Jawa. Hal itu terlihat pada catatan di } \\
\text { bawah ini. } \\
\text { Nuli anyandak alaki Nyai Sri, nyaéta paré iku } \\
\text { ana ing nusa Jawa. } \\
\text { (Tuluy nyandak binih pare, nya éta anu aya di } \\
\text { pulo Jawa.) }\end{array}$ \\
\hline 3. & $\mathrm{SC} / 8 / 1 / 5$ & kulon & $\begin{array}{l}\text { Kata kulon menyimbolkan tempat yang berada } \\
\text { di sebelah barat yang menjadi tujuan perjalanan }\end{array}$ \\
\hline
\end{tabular}




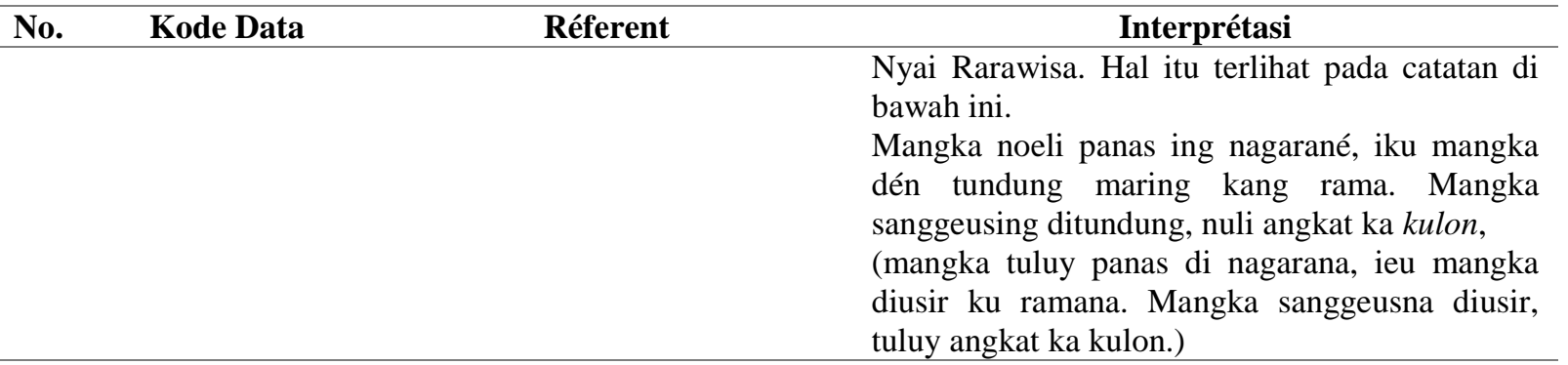

Nilai etnpedagogik naskah Sejarah Cijulang meliputi (1) Catur Jatidiri Insan; (2) Moral Kemanusiaan; dan (3) Gapura Panca Waluya.

Di bawah ini dijelaskan nilai etnpedagogik "Catur Jatidiri Insan" yang meliputi pengkuh agamana (SQ), luhung élmuna (IQ), jembar buadayana (EQ), rancagé gawéna (AQ) (Suryalaga dalam Sudaryat, 2014).

\section{1) Pengkuh Agamana (SQ)}

Pengkuh agamana merupakan kualitas kecerdasan spiritual religiusitas, memiliki perilaku Imtaq sesuai dengan ajaran aqidah agama masing-masing.

Mangka dipernahkeun Nabi Adam maring sawarga, maka sakéhé ruhiyat iko kinon, sujud déning Alloh ta'ala ka Nabi Adam, mangka pada sujud sakéhé para malaikat ka Nabi Adam, anging Idajil la'natulloh anu teu daékeun sujud. Mangka nuli kabendon dening Alloh ta'ala.

(Mangka dipernahkeun Nabi Adam ka sawarga, maka sakabéh ruhiat sujud ka Nabi Adam, mangka pada sujud sakabéh para malaikat ka Nabi Adam, iwal Idajil la'natuloh anu teu daékeun sujud. Mangka tuluy kabendu ku Alloh ta'ala.)

Catatan Sejarah Cijulang di atas menggambarkan bahwa semua mahluk taat kepada perintah Alloh. Ketika Alloh memerintahkan mahluk-Nya supaya bersujud kepada Nabi Adam, maka semua mahluk taat kepada perintah-Nya yaitu bersujud kepada Nabi Adam, kecuali Idajil la'natulloh.

\section{2) Luhung Élmuna}

Luhung elmuna merupakan kulaitas sumber daya manusia yang memiliki kecerdasan dalam mengatasi masalah hidupnya, menguasai iptek, cerdas, tahu, dan berdaya saing.

Mangka nuli angalih Raja Putri ka

Gunung Padang, nuli sujud di Gunung

Padang. Tatkala eukeur sujud, mangka nuli metu cahya tina socané, mangka iku dingaranan Ratu Galuh.

Mangka lawas-lawas ia ratu Galuh, nuli dadi nyakrawati ing Nusa Jawa.

(Mangka tuluy ngalih Raja Putri ka Gunung Padang, tuluy sujud di Gunung Padang. Nalika eukeur sujud, mangka tukuy kaluar cahya tina socana, mangka éta dingaranan Ratu Galuh. Mangka lila-lila manéhna jadi ngawasa di nusa Jawa.)

Dari catatan Sejarah Cijulang di atas terlihat bahwa Raja Putri memiliki ilmu yang luhur, hal itu ditandai dengan adanya cahaya yang keluar dari matanya. Dengan kesaktiannya itu dirinya dinamai Ratu Galuh, serta lama-lama berkuasa di Pulau Jawa.

\section{3) Jembar Budayana}

Jembar budayana merupakan kualitas kecerdasan emosi, berwawasan luas, arif bijaksana, tak gagap budaya, tak kehilangan jatidiri yang manusiawi dan agamis (religius), yang menghargai multietnis dan multikultur.

Barang geus tumetep, lajeng ngadamel panghulu, khalifah sareng pangkat- 
pangkat séjén. Lajeng nikahkeun di dinya.

Dari catatan di atas terlihat bahwa masyarakat pada zaman itu sudah tahu aturan, tahu terhadap sistem pemerintahan dan sebagainya yang diperlukan untuk mengatur serta membantu kehidupannya. Dari catatan Sejarah Cijulang di atas diterangkan bahwa Aki Gede dan pengikutnya menentukan penghulu, khalifah, dan pangkat-pangkat lain yang diperlukan bagi kelangsungan hidup masyarakatnya.

\section{4) Rancagé Gawéna}

Rancage gawena merupakan kulaitas dalam berproses sinergik yang intergral dari IQ, EQ, dan SQ yang beretos kerja tinggi, berprestasi, mampu dalam berprestasi, berperilaku aktif, kreatif, inovatif yang bisa menyesuaikan diri dengan perkembangan zaman dan menguasai zaman.

Kangjeng Nabi Nuh ngadamel parahu anu leuwih gedé. Parantos ngadamel parahu, tuluy Nabi Nuh nyipta angin topan anu gedé sarta banget, datangna angin tina poncoroting sagara. Mangka nuli kakélem alam dunya, antara opat puluh poé. Ari anu anut kana syare'at Nabi Nuh, mangka pada arunggah kana parahu Kangjeng Nabi Nuh sadaya.

(Kangjeng Nabi Nuh ngadamel parahu anu leuwih gedé. Parantos ngadamel parahu, tuluy Nabi Nuh nyipta angina topan anu gedé pisan, datangna tina poncoroting sagara. Mangka tuluy kakélem alam dunya, antara opat puluh poé. Ari anu anut kana syaréat Nabi Nuh, mangka pada arunggah kana parahu Kangjeng Nabi Nuh sadaya.)

Catatan Sejarah Cijulang di atas menerangkan kreatifitas Nabi Nuh ketika membuat perahu yang begitu besarnya untuk menaikan umat-umatnya ketika ada angina topan. Dengan kreatifitasnya bisa menyelesaikan pekerjaan tersebut sampai selesai, serta perahu itu bisa menyelamatkan diri dan umatnya dari angina topan.

\section{Moral Kamanusaan}

Orientasi etnopedagogik Sunda menciptakan manusia yang bermoral atau berkarakter, yakni manusia yang taat pada hukum, berpijak kepada ketentuan Negara, dan bermufakat kepada orang banyak. $\mathrm{Ku}$ kituna catur diri insan mengacu kepada moral kemanusiaan yang menjadi pandangan hidup orang Sunda, yakni (1) moral manusia terhadap Tuhan, (2) moral manusia tehadap pribadi, (3) moral manusia terhadap manusia lainnya, (4) moral manusia terhadap alam, (5) moral manusia terhadap waktu, dan (6) moral manusia dalam mengejar kepuasan lahiriah dan batiniah.

\section{1) Moral Manusia kepada Tuhan}

Moral manusia kepada Tuhan menggambarkan sikap dan perilaku manusia yang taat dalam melaksanakan ajaran agama, toeransi terhadap agama lain, serta hidup rukun dan damai dengan orang yang berbeda agama.

Barang putri sumping ti cai, lajeng murangkalih téh ditéang, bet teu aya.

Ari pilahirna putri: "Emh, geus pinasti kersaning Alloh, murangkalih henteu aya."

Tina cutatan Sajarah Cijulang di luhur katitén pengkuhna iman Putri, hal éta katémbong tina sikep Putri anu pasrah kana papastén ti Alloh. Sanajan manéhna ngarasa sedih lantaran anakna leungit, tapi manéhna teu ngarasula, narima kana takdir anu geus ditangtukeun ku Alloh.

\section{2) Moral Manusa terhadap Pribadi}

Moral manusia terhadap pribadi merupakan sikap manusia dalam hubungannya dengan diri pribadi sebagai individu, yang yang ditandai dengan 
kualitas sumber daya manusia (SDM) atau sumber daya insani (SDI).

Ari Nini, Aki, jeung saréncangna, tuluy angkat deui ngulon, lajeng ngidul. Barang sumping ka pasir, lajeng lirén, ngaso. Ayeuna éta tempat katelah Cikaso.

Catatan Sejarah Cijulang di atas menggambarkan bahwa selaku pribadi kita harus menghargai diri kita sendiri dengan cara memeberi kesempatan kepada diri kita untuk beristirahat dari pekerjaan, istirahat dari kelelahan, serta harus menghargai orang lain. Dari catatan di atas terlihat Aki Gede dan pengikutnya yang telah melakukan perjalanan dari Banyumas, mereka beristirahat dahulu di suatu tempat yang sekarang dikenal sebagai daerah Kawasen dan Cikaso.

\section{3) Moral Manusa kepada Manusa lainnya}

Moral manusa ka manusa mangrupa sikep manusa ka manusa séjén dina kahirupan masarakat, bangsa, nagara, anu ditandaan ku kasadaran ayana masarakat multi-religi, multi-etnis, jeung multikultur.

Moral manusia terhada manusia lainnya merupakan sikap manusia dalam hubungannya dengan manusia lainnya dalam kehidupan bermasyarakat, berbangsa, dan bernegara, yang ditandai dengan kesadaran akan adanya masyarakat yang multi-religi, multi-etnis, dan multikultur.

Ari eukeur ngadawuh kitu, aya sadérékna anu ti Banyumas: atuh buruburu baé ka Kedungrandu bari nyarita, pokna: "Nini, Aki kaula ngadéngé dawuhan Kangjeng Sinuhun yén Nini jeung Aki rék dirurugan. Ayeuna ulah tiis-tiis jahé, kudu geuwat baé leumpang ka Kulon!"

Catatan Sejarah Cijulang di atas menggambarkan bahwa selaku manusia kita harus tolong-menolong. Dalam cerita di atas terlihat kerabat Aki Gede dan Nini Gede memberitahu bahwa Kangjeng Sinuhun akan menyerang Aki Gede dan Nini Gede, dengan demikian diberitahu oleh kerabatnya itu supaya cepat-cepat pergi dari Kedungrandu.

\section{4) Moral Manusa terhadap Alam}

Moral manusia terhadap alam merupakan sikap manusia dalam hubungannya dengan lingkungan alam, ditandai dengan kesadaran ekologi/ ekosistem dan geopolitics/kewilayahan. Sikap dan tindakan yang selalu berupaya mencegah kerusakan pada lingkungan alam di sekitarnya dan mengembangkan upaya-upaya untuk memperbaiki kerusakan alam yang sudah terjadi.

Mangka sanggeusing dikubur iku lawas-lawas aya anu jadi, bijil tina lebah nétrané, jadi warna-warni rupané, nuli dingaranan paré jeung sakéhé panganan anu leuwih énak. Mangka kang putra ratu Mesir, namané Ratu Perwatasari, mangka dihaturkeun ka Ratu Medangkamulyan; balané séwu. Nuli anyandak alaki Nyai Sri, nyaéta paré iku ana ing nusa Jawa.

(Mangka sanggeus dikubur éta lila-lila aya anu jadi, bijil tina lebah matana, jadi rupa-rupa, tuluy dingaranan pare jeung saniskara kadaharan anu leuwih énak. Mangka putra Ratu Mesir anu ngaranna Ratu Perwatasari dipasrahkeun ka Ratu Medangkamulyan; baladna sarébu. Tuluy nyandak binih pare, nya éta pare anu aya di nusa Jawa.)

Dari catatan Sejarah Cijulang di atas terlihat bahwa manusia harus memelihara tumbuh-tumbuhan, apalagi tumbuhan itu merupakan tumbuhan sumber makanan pokok. Yaitu tumbuhan padi.

\section{5) Moral Manusa terhadap Waktu}

Moral manusia terhadap waktu merupakan sikap manusia dalam hubungannya 
dengan pemanfaatan waktu, ditandai dengan kesadaran akan adanya waktu linear, waktu cyclis, dan waktu baqa. Manusia yang tidak menghargai akan mendapat kerugian.

Ari dawuhan Kangjeng Sinuhun: "Naha manéh boga anak dipundut ku kami teu dibikeun. Seug ayeuna mah manéh ku kami rék dipentaan mu’jijat, kudu nyieun bale tilu suhunan, jeung kudu ngarupakeun onén-onén anu gedé tur punjul ti batur, jeung sarana anu punjul ti batur sarta kudu rupa sapeuting ieu pisan.

Ari ku Nini Gedé jeung Aki Gedé disanggupan baé, sarta sapamundut Sinuhun sapeuting éta rupa.

Dari catatan Sejarah Cijulang di atas terlihat bahwa kita harus menghargai waktu. Sebab waktu bisa menentukan nasib kita kedepannya. Misalnya waktu bisa menentukan kebijakan, atau bisa juga menentukan hidup dan mati. Dari cerita di atas Aki Gede dan Nini Gede melaksanakan permintaan Kangjeng Sinuhun membuat bangunan yang megah dalam waktu satu malam. Hal itu disanggupi oleh Aki Gede demi mebela anaknya supaya tidak dipinta oleh Kangjeng Sinuhun.

\section{6) Moral Manusa dalam Mengejar Kepuasan Lahiriah dan Batiniah}

Moral manusia dalam mengejar kepuasan lahiriah dan batiniah merupakan sikap dan perilaku manusia dalam memenuhi kebutuhan serta kepuasan lahir batin, yang ditandai dengan kesadaran etika dan estetika.

Énggalna, lajeng baé ngalih $k a$ Gurago. Sasumpingna, lajeng ngadamel bumi hiji, balé hiji, masigit hiji, jeung papanggungan hiji.

Dari catatan Sejarah Cijulang di atas terlihat bahwa pada umumnya manusia itu mencari ketentraman hidup yang meliputi kepuasan lahiriah dan batiniah. Dari cerita di atas terlihat bahwa masyarakat jaman dulu memenuhi salahsatu kepuasan lahiriah dengan cara mebuat rumah, balai, dan papanggungan. Sedangkan untuk memenuhu kepuasan batiniah mereka membuat masjid untuk tempat ibadah kepada Alloh supaya mendapat rasa tentram dalam hati dengan cara mentaati perintah Alloh yaitu melakukan ibadah sholat.

Etnopedagogik Sunda mendorong kegiatan pendidikan dan pembelajaran untuk memasuki Gapura Panca Waluya (gerbang kesempurnaan), yaitu cageur, bageur, bener, pinter, singer, yang dikukuhkan dengan karakter pangger.

\section{1) Cageur}

Cageur merupakan keadaan sehat, baik sehat jasmanai maupun sehat rohani atau sehat lahir dan batin. Proses belajar akan berjalan dengan baik apabila keadaan peserta didik sehat.

Barang sumping ka hiji walungan, lajeng mareuntas; anu ayeuna katelah hanjatan Manganti. Ari parantos mareuntas, tuluy ngarereb di dinya; ayeuna anu katelah Kawasén.

Nilai etnopedagogik cageur yang ditemukan dalam naskah Sejarah Cijulang ini umumnya ditandai dengan kemampuan masyarakat jama dulu yang mampu melakukan perjalanan yang begitu jauh dengan jalan kaki, pindah dari satu tempat ke tempat yang lain. Selain sehat jasmani juga sehat rohani yang ditandai dengan keimanan masyarakat jaman dulu yang ditandai dengan adanya masjid selaku tempat ibadah.

\section{2) Bageur}

Bageur merupakan keadaan atau karakter yang baik hati, sederhana, dan tidak sombong. Orang yang baik hati akan berperilaku santun, menghormati dirinya dan orang lain. Orang yang baik hati akan menghargai guru, pemimpin, dan kedua orang tua. 
Punika margané anak putu Ratu Sunda bubaran saking Pajajaran, ditundung $k u$ kang rama sanggeus meunang wurukan ti Kiyai An Sancang samulihna saking Mekah, nuli ka putra kekel imanna lan islamna, tegesna henteu anut kana syaré at kang rama; margané ditundung , sabab matak pamos ka nagara Pakuan, anu matak leumpang ka ratu Cempa.

(Ieu sabab anak incu Ratu Sunda kaluar ti Pajajaran, diusir ku ramana sanggeus meunang wurukan ti Kiyai An Sancang samulihna ti Mekah, tuluy putrana kekel Iman jeung Islamna, tegesna henteu anut kana syaréat ramana; sabab diusir, sabab matak pamos ka nagara Pakuan, anu matak leumpang ka Ratu Cempa.)

Catatan Sejarah Cijulang di atas menunjukan sikap baik hati anak cucu Ratu Sunda yang diusir oleh ayahnya dari Pajajaran. Walaupun dia di usir oleh ayahnya tapi dia tetap tegar, serta menerima keingina ayahnya yang menyuruhnya pergi dari Pajajaran karena dia mempertahankan keyakinannya setelah mendapat ajaran dari Kiyai An Sancang di Mekah.

\section{3) Bener}

Bener merupakan keadan atau karakter manusia yang benar, yakni taat pada hukum dan menjalankan syariat agama. orang yang benar akan taat kepada Alloh, kepada Rosul, dan kepada pemimpin Negara.

Mangka nuli kabendon Nabi Adam jeung Babu Hawa ku Alloh ta'ala. Lajeng sujud bari tobat Nabi Adam jeung Babu Hawa, tina kaluluputanana, tegesna nyuhunkeun pangampurana Alloh ta'ala.

(Mangka tuluy kabendon Nabi Adam jeung Babu Hawa ku Alloh ta'ala. Lajeng sujud bari tobat Nabi Adam jeung Babu Hawa, tina kaluluputanana, tegesna nyuhunkeun pangampura Alloh ta'al.)

Catatan Sejarah Cijulang di atas menunjukan bahwa selaku manusia kita harus taat pada perintah Alloh, ketika kita melakukan kesalahan atau dosa harus segera bertobat meminta pengampunan kepada Alloh. Dari catatan di atas terlihat Nabi Adam dan Babu Hawa yang sujud meminta pengampunan Alloh setelah melakukan kesalahan.

\section{4) Pinter}

Pinter merupakan keadaan atau karakter manusia yang memiliki ilmu pengetahuan. Orang yang pintar harus seperti ilmu padi yakni semakin berisi semakin merunduk, semakin tinggi ilmunya semakin merendah.

Idajil ngarupakeun simeut, $k u$ merak henteu dipacok; ngarupakeun beunceuh henteu dipacok kénéh. Tuluy ngarupakeun lombok, énggal ku merak dipacok, diisingkeun kana jero tempatna Kangjeng Nabi Adam. Tuluy baé Idajil ngadeuheusan ka Kangjeng Nabi Adam.

Sebab ingin masuk lagi ke dalam surga untuk menggoda Nabi Adam, Idajil beruasaha melakukan apa saja. Idajil tudak bisa masuk ke dalam surge sebab dijaga oleh burung merak, ahirnya Idajil berfikir, mencari cara agar bisa masuk ke dalam surge sarta lolos dari pengawasan burung merak. Ahirnya Idajil berubah menjadi belalang agar dipatuk burung merak. Tapi tetap tidak dipatuk. Kemudian berubah jadi jangkrik, tetap tidak dipatuk. Ahirna berubah menjadi cabe rawit, dan langsung dipatuk oleh burung merak. Sesudah dipatuk kemudian dikeluarkan dalam bentuk kotoran di dalam surge, tempat Nabi Adam dan Babu Hawa berada. Hal itu 
menunjukkan bahwa Idajil memiliki ilmu yang tinggi.

\section{5) Singer}

Singer merupakan keadaan atau karakter manusia yang terampil atau piawai, yakni manusia yang serba bisa atau banyak keterampilannya dan bersifat aktif, kreatif, dan inovatif.

Kangjeng Nabi Nuh ngadamel parahu anu leuwih gedé. Parantos ngadamel parahu, tuluy Nabi Nuh nyipta angin topan anu gedé sarta banget, datangna angin tina poncoroting sagara. Mangka nuli kakélem alam dunya, antara opat puluh poé. Ari anu anut kana syare'at Nabi Nuh, mangka pada arunggah kana parahu Kangjeng Nabi Nuh sadaya.

(Kangjeng Nabi Nuh ngadamel parahu anu leuwih gedé. Parantos ngadamel parahu, tuluy Nabi Nuh nyipta angina topan anu gedé pisan, datangna tina poncoroting sagara. Mangka tuluy kakélem alam dunya, antara opat puluh poé. Ari anu anut kana syaréat Nabi Nuh, mangka pada arunggah kana parahu Kangjeng Nabi Nuh sadaya.)

Dari catatan Sejarah Cijulang di atas terlihat bahwa Nabi Nuh merupakan manusia yang luhur ilmunya, terampil dan pawai. Hal itu ditandai dengan bisa membuat perahu yang begitu besarnya serta bisa menciptakan angina topan.

\section{6) Pangger}

Pangger merupakan keadaan atau karakter manusia yang kukuh, berdedikasi tinggi, dan berkomitmen. Tangguh dalam membela kebenaran, tidak berhianat, setia, dan tidak ingkar janji.

Punika margané anak putu Ratu Sunda bubaran saking Pajajaran, ditundung $k u$ kang rama sanggeus meunang wurukan ti Kiyai An Sancang samulihna saking Mekah, nuli ka putra kekel imanna lan islamna, tegesna henteu anut kana syaré 'at kang rama; margané ditundung, sabab matak pamos ka nagara Pakuan, anu matak leumpang ka ratu Cempa.

(Ieu sabab anak incu Ratu Sunda kaluar ti Pajajaran, diusir ku ramana sanggeus meunang wurukan ti Kiyai An Sancang samulihna ti Mekah, tuluy putrana kekel Iman jeung Islamna, tegesna henteu anut kana syaréat ramana; sabab diusir, sabab matak pamos ka nagara Pakuan, anu matak leumpang ka Ratu Cempa.)

Catatan Sejarah Cijulang di atas menunjukkan kebenaran mengenai anak cucu Ratu Sunda yang memilih diusir oleh ayahnya karena tidak menuruti perintahnya, tapi tetap teguh pendirian terhadap keimanannya setelah mendapat ajaran dari Kiyai An Sancang dari Mekah.

\section{SIMPULAN}

Penelitian ini membahas naskah Sajarah Cijulang dari segi struktural, semiotik, dan etnopedagogiknya. Dari hasil penelitian terlihat bahwa alur cerita Sajarah Cijulang menggunakan alur maju yang dibagi menjadi beberapa episode. Episode pertama menceritakan asal mula diciptakannya alam dunia, Nabi Adam, dan silisah raja-raja Sunda. Episode kedua menceritakan perjalanan Aki Gede dan Nini Gede dari Kedungrandu ke Gurago. Episode ketiga meneritakan Sembah Agung yang di Taal. Karakter dalam naskah Sajarah Cijulang merupakan tokoh-tokoh fiksi dan tokoh-tokoh sejarah. Latar yang ada dalam cerita Sajarah Cijulang merupakan tempattempat yang ada disekitar daerah Cijulang. Dalam naskah Sajarah Cijulang ditemukan 59 unsur semiotik yang meliputi ikon $8,5 \%$, indeks 59,3\%, simbol 32,2\%. Dari hasil analisis naskah Sajarah Cijulang ditemukan 146 nilai etnopedagogik yang meliputi nilai 
etnopedagogik moral kemanusiaan 45,2\%, gapura panca waluya $32,9 \%$, dan catur jatidiri insan 21,9\%. Berdasarkan hasil penelitian Sejarah Cijulang ulikan struktural, semiotik, dan etnopedagogik. Saran yang berkaitan dengan penelitian seperti di bawah ini:

1) Penelitian ini bisa jdijadikan bahan pertimbangan untuk pemerintah dalam menjaga karya sastra lama yang memiliki nilai luhur;

2) Penelitian ini salahsatu upaya untuk mengetahui dan mempertahankan nilainilai etnopedagogik yang bisa memberi muatan positif bagi masyarakat;

3) Penelitian ini hanya menjadi salahsatu jalan untuk mengadakan penelitian yang lebih mendalam lagi. Sebab masih banyak nilai-nilai yang terdapat dalam naskah Sejarah Cijulang yang perlu diungkap.

\section{PUSTAKA RUJUKAN}

Budiman, Kris. (2011). Semiotoka visual: Konsep, isu, dan problem Ikonisitas. Yogyakarta: Jalasutra.

Luxemburg, J. V. spk. (1992). Pengantar ilmu sastra. Jakarta: Gramedia Pustaka Utama.

Pradopo, Rachmat Djoko. (2010). Beberapa teori sastra, metode kritik, dan penerapannya. Yogyakarta: Pustaka Pelajar.

Ruhaliah. (2015). Pendidikan karakter dalam sastra sunda klasik. Pendidikan karakter dalam budaya sunda dan jepang: Sebuah kajian perbandingan, kc. 41-60.

Stanton, Robert. (2007). Teori fiksi robert stanton. Yogyakarta: Pustaka Pelajar.

Sudaryat, Yayat. (2014). Wawasan kesundaan. Bandung: Jurusan Pendidikan Bahasa Daerah FPBS UPI.

Syuropati, Mohammad A. (2003). Teori sastra kontemporer dan 13 tokohnya. Yogyakarta: In Azna Book.

\section{UCAPAN TERIMA KASIH}

Ucapan syukur yang tiada henti untuk diucapkan ketika tesis ini selesai. Usaha, do'a serta dukungan dari beberapa pihak yang tiada henti sampai tesis ini selesai. Oleh karena itu penulis mengucapkan banyak terimaksih kepada (1) Dr. Ruswendi Permana, M.Hum. selaku dosen pembimbing yang senantiasa sabar dalam membimbing ketika menyelesaikan tesis ini; (2) Dr. H. Yayat Sudaryat, M.Hum. selaku Ketua Program Studi Pendidikan Bahasa dan Budaya Sunda Pascasarjana UPI; (3) Dr. Ruhaliah, M.Hum. selaku dosén pembimbing akademik yang sudah mendampingi selama kuliah di Prodi Pendidikan Bahasa dan Budaya Sunda Pascasarjana UPI; dan (4) Ibu dan Bapa Dosén Pascasarjana Prodi Pendidikan Bahasa dan Budaya Sunda; Terimakasih atas segala perhatian dan dukungannya, semoga amal kebaikannya mendapat ganjaran dari Alloh swt. 